\title{
Salt Distribution and Salt Uptake during Ripening in Turkish White Cheese Affected by High Pressure Processing
}

\author{
Nurcan Koca $^{1 *}$, Raghu Ramaswamy², VM Balasubramaniam ${ }^{3,4}$, W James Harper ${ }^{3}$ \\ ${ }^{I}$ Department of Food Engineering, Faculty of Engineering, Ege University, 35100 Bornova/Izmir, Turkey \\ ${ }^{2}$ Kraft Heinz Company, Pittsburg, PA, USA \\ ${ }^{3}$ Department of Food Science and Technology, The Ohio State University, 43210-1007 Columbus, OH, USA \\ ${ }^{4}$ Department of Food Agricultural, Biological Engineering, The Ohio State University, 43210 Columbus OH, USA \\ A R T I C LE IN F O A B S TR A C T

\section{Research Article} \\ Received 04 October 2017 \\ Accepted 31 January 2018 \\ Keywords: \\ High pressure processing \\ Salt distribution \\ Salt uptake \\ Turkish white cheese \\ Ripening \\ *Corresponding Author: \\ E-mail: nurcan.koca@ege.edu.tr \\ Turkish white cheeses after brine salting were subjected to high pressure processing \\ (HPP) at 50, 100, 200 and $400 \mathrm{MPa}$ for 5 and $15 \mathrm{~min}$ and the samples pressurized for 15 \\ min were ripened in brine for 60 days. The effects of HPP on the salt distribution in \\ external, middle and internal zones of cheese after pressurization and on the salt uptake of \\ whole cheese block during ripening were investigated. HPP did not change the values of \\ moisture, salt and salt in moisture in different zones of cheese. Furthermore, pressure \\ holding time had no effect on salt distribution in cheese. The salt contents of un- \\ pressurized and pressurized cheese samples were equilibrated on the $14^{\text {th }}$ day of ripening, \\ and then stabilized, with no high pressure effect. As a result, HPP at pressures up to 400 \\ MPa did not significantly affect neither salt distribution after high pressure processing nor \\ salt uptake during ripening. However, a slight increase in moisture at the pressures of \\ 200-400 $\mathrm{MPa}$ on the $60^{\text {th }}$ day of ripening, which was not significant, might warn further \\ increases in moisture of white cheese for longer ripening periods than 60 days. Higher \\ pressure applications may alter all those values in white cheese because of textural \\ changes.
}

DOI: https://doi.org/10.24925/turjaf.v6i4.433-437.1616

\section{Introduction}

Turkish white cheese is a brine-salted cheese variety with a semi-soft or semi-hard texture, and salty and acidic taste and ripened in the brine for 1-3 months (Hayaloglu et al., 2002). Salt plays an important role in cheese ripening by controlling microbial growth, enzyme activity and biochemical changes, and in turn, affects cheese quality (Guinee, 2004; Wick et al., 2004). The amount of salt absorbed during salting step is affected by the salt concentration in brine, the cheese geometry, the brining time, the temperature of the curd and brine, the curd $\mathrm{pH}$, and the curd composition (Guinee and Fox, 2004). Salt diffuses from the surface to the center during salting of cheese block in brine. After salting or at the beginning of ripening, the amounts of salt and salt in moisture vary in different zones within a cheese loaf (Luna and Chavez, 1992). The zonal variations changes until the level of saltin-moisture is equilibrated as the ripening time progresses (Guinee and Fox, 2004). Although little research on the factors affecting the salt diffusion during ripening has been found, the factors affecting the salt diffusion during ripening is similar to those in salting step according to Guinee (2004). The textural properties of cheese can also alter the salt diffusion during both salting step and ripening period. The textural and structural changes in cheese during HPP were reported by Kolakowski et al. (1998), Messens et al. (2000), Wick et al. (2004) and Koca et al. (2011). The degree of these changes depends on cheese variety and pressure level.

In literature, HPP was studied in order to accelerate cheese brining in Gouda cheese (Messens et al., 1999) and Manchego-type cheese (Pavia et al., 2000). However, there has been no attempt to figure out whether salt distribution in already salted cheese is altered by HPP. Messens et al. (1999) also studied the salt and water profiles of Gouda cheese pressurized at $400 \mathrm{MPa}$ during 27 days of ripening and found that pressure treatment had no effect on the salt equilibrium at an earlier ripening stage. In this research, Gouda cheese samples were vacuum-packaged and left for ripening at $14^{\circ} \mathrm{C}$. However, Turkish white cheese, semi-soft cheese, ripens in brine, which means that cheese continues to absorb salt from brine in tin while the salt transports to the center of it. In previous study, Koca et al. (2011) reported structural changes in high pressurized white cheese depending on the pressure level and time. Therefore, the structural changes resulted by HPP could have more effects on salt 
profiles in white cheese than those of the cheese ripened in vacuum package, due to the additional salt uptake during ripening. Actually, higher salt absorption from brine by white cheese during ripening is not desired because of quality and health aspects.

In this study, the effects of HPP on salt distribution of Turkish white cheese and its salt uptake during ripening were aimed to determine. The research was carried out in two parts: 1) The salt distribution of salted cheese after HPP was investigated, 2) The salt uptake of pressurized cheese during ripening were determined.

\section{Materials and Methods}

\section{Materials}

The whole cow milk was provided from The Ohio State University (Columbus, OH, USA) Holstein herd at the day of cheese production. The mesophilic culture (Lactococcus lactis and L. cremoris) and thermophilic culture (Streptococcus thermophiles, Lactobacillus bulgaricus, L. helveticus) and CHY-MAX ${ }^{\circledR}$ fermentation derived chymosin were supplied by CHR-Hansen (Milwaukee, WI, USA).

\section{Cheese Production}

Cheese production was carried out in Dairy Pilot Plant of Food Science and Technology Department of The Ohio State University. Whole milk was separated to cream and non-fat milk with separator. Then, the fat:protein ratio of milk was standardized to $1: 1$. Standardized milk was pasteurized at $63^{\circ} \mathrm{C}$ for 30 minutes and cooled down to $31 \pm 1{ }^{\circ} \mathrm{C}$. Bulk starter culture $(10 \mathrm{~g} / \mathrm{kg})$ including mesophilic (Lactococcus lactis and L. cremoris) and thermophilic cultures (Streptococcus thermophilus and Lactobacillus bulgaricus, L. helveticus) in the ratio of $1: 1$ and $\mathrm{CaCl}_{2}$ of $40 \%$ solution $(0.2 \mathrm{~g} / \mathrm{kg})$ were added. When the $\mathrm{pH}$ of milk was at 6.4-6.45, rennet was added to milk to complete the coagulation within $90 \mathrm{~min}$. The curd was cut with a curd knife into $1-2 \mathrm{~cm}^{3}$. The curd was allowed to settle for $10 \mathrm{~min}$ and transferred into the mold covered with cheese cloth. After $30 \mathrm{~min}$, press was applied for 4 hours by increasing press weight as $10 \mathrm{~kg}$ incrementally for every $30 \mathrm{~min}$ until $50 \mathrm{~kg}$ pressing for $150 \mathrm{~L}$. When the $\mathrm{pH}$ of curd was reached to 4.85-4.90, cheese block was divided into rectangular blocks $(10 \times 7 \times 6$ $\mathrm{cm}$ and 380-390 $\mathrm{g}$ weight). The cheeses left in brine $(14 \mathrm{~g}$ $\mathrm{NaCl} / 100 \mathrm{~g}$ water) twice as much as the amount of cheese at $22 \pm 1{ }^{\circ} \mathrm{C}$ for 6 hours. Then, cheese blocks were kept in refrigerator overnight at $8-10^{\circ} \mathrm{C}$. The next day, all samples were subjected to HPP and placed at $4^{\circ} \mathrm{C}$ immediately after HPP. The samples to be ripened at around $8^{\circ} \mathrm{C}$ were packaged in the air- and water-tight durable polypropylene plastic containers of $470 \mathrm{ml}$. brine $\left(14 \mathrm{~g} \mathrm{NaCl} / 100 \mathrm{~g}\right.$ water) at $8^{\circ} \mathrm{C}$, was added into containers to cover the samples with brine and the containers were closed carefully by ensuring no air in. Cheese samples pressurized for $15 \mathrm{~min}$ were ripened at $8^{\circ} \mathrm{C}$ for 14 days and at $4^{\circ} \mathrm{C}$ till 60 days. The textural changes were more obvious in samples pressurized for $15 \mathrm{~min}$ according to Koca et al., (2011). That is why, the samples pressurized for only $15 \mathrm{~min}$ were chosen for determination of salt uptake during ripening period.

\section{High Pressure Processing}

The next day of production, after removing residual surface salt by wiping, each block was vacuum packaged in double high barrier pouches (P640B film, Cryovac, Sealed Air Corp., Duncan, SC) just before HPP. The temperatures of samples were adjusted before HPP, ranging from $2^{\circ} \mathrm{C}$ to $20^{\circ} \mathrm{C}$ in order to reach to $22 \pm 2^{\circ} \mathrm{C}$ at the end of come up time. Samples were then subjected to $\mathrm{HPP}$ at 50, 100, 200 and $400 \mathrm{MPa}$ and $22 \pm 2^{\circ} \mathrm{C}$ for 5 and 15 minutes in a Quintus High Pressure Food Processor with a $2 \mathrm{~L}$ pressure chamber (QFP-6, ABB Autoclave Systems Inc., Columbus, OH, USA). A water/propylene glycol mixture (1:1) was used as the pressure transmitting fluid, the temperature of which was kept at $22 \pm 2^{\circ} \mathrm{C}$ during process, by setting the temperature of water-jacket surrounding the chamber. Pressure, transmitting fluid temperature representing the product temperature and water-jacket temperature were monitored by using a Hewlett Packard data acquisition system (HP75000, Series B, model E1301A) supported by a HPVEE Windows compatible software (Hewlet-Packard Comp., Palo Alto, CA). Non-pressure treated control at atmospheric pressure $(0.1 \mathrm{MPa})$ was vacuum packaged as well and kept at room temperature until its temperature reached to $22 \pm 2^{\circ} \mathrm{C}$.

\section{Experimental Design and Cheese Sampling}

Cheese samples were produced duplicate in two different days and two cheese blocks from each repeat were analyzed. For determining the salt distribution just after HPP, four different pressures (50, 100, 200 and 400 $\mathrm{MPa}$ ) with two different holding times (5 and $15 \mathrm{~min}$ ) were used. The HP processed cheese blocks were kept for about 3 hours at $4^{\circ} \mathrm{C}$ in order to make the sampling easier. Whole cheese blocks were then sampled as external, middle and internal zones as shown in Figure 1 according to Guamis et al. (1997) in order to determine the salt distribution. All the amounts for each zone were grated, vacuum-packaged and stored at $4^{\circ} \mathrm{C}$ until analyzing.

For determining salt uptake during ripening, cheese blocks treated for just 15 minutes were ripened for 60 days and analyzed on the $1^{\text {st }}, 14^{\text {th }}, 30^{\text {th }}$ and $60^{\text {th }}$ days of ripening. Cheeses were sampled according to ISO 707/IDF 50 (2008), representing whole cheese block.

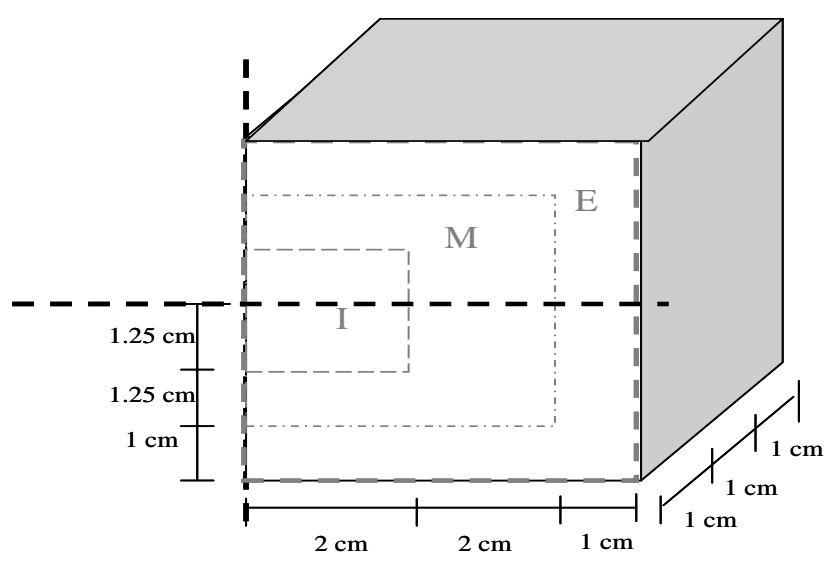

Figure 1 Cheese sampling for determining the salt distribution after HPP. I: internal, M: middle, E: external

(Figure represents one quarter of cheese block) 


\section{Salt and Moisture Analysis}

Salt content was determined with an M-926 Chloride Analyzer (Nelson and Jameson Inc., USA). Moisture was determined by gravimetric method in a vacuum oven (Bradley et al., 1992). Because of the importance of salt in moisture for microbial growth during ripening, the level of salt in moisture of cheese samples was calculated.

\section{Statistical Analysis}

One-way analysis of variance for the data of salt distribution (the factor being the pressure) and two-way analysis of variance for the data of salt uptake during ripening (the factors being the pressure and the ripening period) were carried out to determine the significance of the individual differences (SPSS 14.0, SPSS Inc., USA). P-values $\leq 0.05$ were considered significant. Significant means were compared using Tukey's test on the level of $\alpha=0.05$.

\section{Results and Discussion}

The Effect of HPP on Salt Distribution in White Cheese

The different zones of pressurized cheese samples were analyzed to determine how salt distribution in different zones would be changed by HPP. The values of moisture, salt and salt-in-moisture (SM) in the external, middle and internal zones of control cheese and pressurized cheeses after HPP are given in Table 1. No significant differences $(\mathrm{P}>0.05)$ in moisture content were found between un-treated and HP treated samples for all zones and for both 5 and 15 minutes of pressure time. Similar to present results, Pavia et al. (2000) reported no significant differences in moisture between un-pressure and high pressure brined Manchego cheeses at $50 \mathrm{MPa}$ and $200 \mathrm{MPa}$. Messens et al. (1999) reported higher water losses in high pressure brined Gouda cheese at pressures up to $200 \mathrm{MPa}$, but lower water losses from 200-300 $\mathrm{MPa}$ and attributed it to the different casein dissociates and reassociates and the decrease in the amount of free water in cheese. In present study, no water loss was observed in white cheese at the pressures from $50 \mathrm{MPa}$ to $400 \mathrm{MPa}$ during HPP application. That brining and HPP were carried out at the same time should be emphasized for both previous researches in order to clarify the experimental differences between them and present study. Indeed, during brining, while the salt in brine diffuses into cheese, water in cheese tends to move to opposite direction of salt (Guinee, 2004). One of the aims of salting is to create its desired texture and rind for every cheese type. Some preliminary trials were done for HP brining of Turkish white cheese. Nevertheless, the surface and texture of white cheese blocks at even lower pressures were not as it needs to be. Brining time for white cheese, semi-soft cheese, was probably not enough long to lose the water from cheese, in turn to obtain its desired texture. That is why, cheese samples were subjected to HPP just after brining. Hence, neither the pressure level (up to $400 \mathrm{MPa}$ ) nor pressure holding time (5 and $15 \mathrm{~min}$ ) resulted in water movement in solid white cheese block.

As expected, the levels of salt and salt-in-moisture decreased from the surface to the center of cheese block after salting. The salt and SM values of the internal zones of all cheese samples were the same as those of unsalted cheese. Similar to water, HPP up to $400 \mathrm{MPa}$ did not significantly alter the salt and SM values of each zone in white cheese $(P>0.05)$, showing that the salt in the external zone of cheese sample did not diffuse through the center by HP treatment. Pressure holding time had no significant effect on salt distribution as well $(\mathrm{P}>0.05)$. Pavia et al. (2000) and Messens et al. (1999) also found that the salt diffusion was not accelerated by high pressure brining.

\section{The Effect HPP on The Salt Uptake During Ripening}

The changes in moisture and salt contents of white cheese samples pressurized at 50-400 MPa for $15 \mathrm{~min}$ and ripened in brine for 60 days are given in Table 2. No significant differences were found in moisture and salt contents between control and pressurized cheese samples in terms of each ripening day although the moisture content of the cheese sample pressurized at 200 and 400 MPa for $15 \mathrm{~min}$ on $60^{\text {th }}$ day was slightly higher than those of others $(\mathrm{P}>0.05)$. In previous study on white cheese, softer and more compact texture was obtained at pressures exceeding $200 \mathrm{MPa}$ for $15 \mathrm{~min}$ (Koca et al., 2011). The fact that the texture of cheese samples pressurized at 200 and $400 \mathrm{MPa}$ was softer could be reason of this slight increase in moisture, which was not significant $(\mathrm{P}>0.05)$. Contrary to obtained result, more evident differences in salt permeability in HP treated cheese could have been expected because of the disruption of casein micelle structure by HPP. The similar salt and moisture contents obtained in control and pressurized cheese could be attributed to the denser structure in HP treated cheese, resulting in the lower amount of free water. However, the higher pressures than $400 \mathrm{MPa}$ might change the situation with an evident change in texture of cheese. No research dealing with the salt uptake during ripening on HP treated cheese ripened in brine has been found in the literature. There has been one research, studying the water and salt profiles of HP treated Gouda cheese ripened in vacuum package, not in brine, by Messens et al. (1999) who reported that pressure treatment had no significant effect on these parameters during 27 days of ripening.

The salt in moisture is very important for the growth of microorganisms and ripening of cheese. The low level of salt in moisture may lead the starter activity and accelerate the ripening (Fox et al., 2017). Therefore, the salt in moisture contents of cheeses samples was calculated. The same trend as salt contents in the same ripening day was observed $(\mathrm{P}>0.05)$, which is clearly shown in Figure 2a. 
Table 1 The moisture and salt distribution (mean \pm standard deviation) of brined-white cheese samples after HPP

\begin{tabular}{|c|c|c|c|c|c|c|c|}
\hline \multirow{2}{*}{$\mathrm{P}$} & \multirow{2}{*}{$\mathrm{T}$} & \multicolumn{2}{|l|}{ Moisture (\%) } & \multicolumn{2}{|l|}{ Salt (\%) } & \multicolumn{2}{|c|}{ Salt in moisture (\%) } \\
\hline & & $\mathrm{M}$ & I & $\mathrm{M}$ & I & $\begin{array}{ll}\mathrm{E} & \mathrm{M} \\
\end{array}$ & I \\
\hline $\mathrm{C}$ & & $47.89 \pm 0.21^{\mathrm{a}} 49.10 \pm 1.08^{\mathrm{a}}$ & $48.37 \pm 1.31^{\mathrm{a}}$ & $2.48 \pm 0.10^{\mathrm{a}} 0.37 \pm 0.04^{\mathrm{a}}$ & $0.13 \pm 0.00^{\mathrm{a}}$ & $5.17 \pm 0.20^{\mathrm{a}} 0.74 \pm 0.08^{\mathrm{a}}$ & $0.28 \pm 0.00^{\mathrm{a}}$ \\
\hline \multirow{2}{*}{50} & 5 & $48.56 \pm 1.11^{\mathrm{a}} 49.34 \pm 0.56^{\mathrm{a}}$ & $48.37 \pm 0.33^{\mathrm{a}}$ & $2.50 \pm 0.04^{\mathrm{a}} 0.35 \pm 0.05^{\mathrm{a}}$ & $0.15 \pm 0.00^{\mathrm{a}}$ & $5.15 \pm 0.04^{\mathrm{a}} 0.70 \pm 0.09^{\mathrm{a}}$ & $0.33 \pm 0.01^{\mathrm{a}}$ \\
\hline & 15 & $48.16 \pm 0.29^{\mathrm{a}} 49.24 \pm 1.00^{\mathrm{a}}$ & $49.13 \pm 0.62^{\mathrm{a}}$ & $2.48 \pm 0.04^{\mathrm{a}} 0.35 \pm 0.04^{\mathrm{a}}$ & $0.14 \pm 0.01^{\mathrm{a}}$ & $5.13 \pm 0.09^{\mathrm{a}} 0.71 \pm 0.10^{\mathrm{a}}$ & $0.29 \pm 0.03^{\mathrm{a}}$ \\
\hline \multirow{2}{*}{100} & 5 & $48.71 \pm 0.39^{\mathrm{a}} 49.67 \pm 0.78^{\mathrm{a}}$ & $48.98 \pm 0.65^{\mathrm{a}}$ & $2.40 \pm 0.11^{\mathrm{a}} 0.37 \pm 0.06^{\mathrm{a}}$ & $0.15 \pm 0.00^{\mathrm{a}}$ & $4.93 \pm 0.27^{\mathrm{a}} 0.74 \pm 0.10^{\mathrm{a}}$ & $0.30 \pm 0.01^{\mathrm{a}}$ \\
\hline & 15 & $48.87 \pm 0.01^{\mathrm{a}} 48.54 \pm 1.12^{\mathrm{a}}$ & $50.45 \pm 1.13^{\mathrm{a}}$ & $2.58 \pm 0.10^{\mathrm{a}} 0.34 \pm 0.01^{\mathrm{a}}$ & $0.16 \pm 0.00^{\mathrm{a}}$ & $5.28 \pm 0.18^{\mathrm{a}} 0.70 \pm 0.04^{\mathrm{a}}$ & $0.31 \pm 0.02^{\mathrm{a}}$ \\
\hline \multirow{2}{*}{200} & 5 & $48.88 \pm 0.51^{\mathrm{a}} 50 . .59 \pm 0.94^{\mathrm{a}}$ & $51.34 \pm 1.32^{\mathrm{a}}$ & $2.41 \pm 0.01^{\mathrm{a}} 0.40 \pm 0.07^{\mathrm{a}}$ & $0.15 \pm 0.00^{\mathrm{a}}$ & $4.93 \pm 0.05^{\mathrm{a}} 0.78 \pm 0.00^{\mathrm{a}}$ & $0.28 \pm 0.01^{\mathrm{a}}$ \\
\hline & 15 & $48.41 \pm 0.11^{\mathrm{a}} 49.00 \pm 0.60^{\mathrm{a}}$ & $49.50 \pm 2.13^{\mathrm{a}}$ & $2.50 \pm 0.02^{\mathrm{a}} 0.39 \pm 0.05^{\mathrm{a}}$ & $0.15 \pm 0.00^{\mathrm{a}}$ & $5.16 \pm 0.04^{\mathrm{a}} 0.80 \pm 0.12^{\mathrm{a}}$ & $0.31 \pm 0.01^{\mathrm{a}}$ \\
\hline \multirow{2}{*}{400} & 5 & $49.51 \pm 0.75^{\mathrm{a}} 50.38 \pm 1.19^{\mathrm{a}}$ & $50.39 \pm 1.97^{\mathrm{a}}$ & $2.55 \pm 0.09^{\mathrm{a}} 0.39 \pm 0.04^{\mathrm{a}}$ & $0.15 \pm 0.00^{\mathrm{a}}$ & $5.16 \pm 0.11^{\mathrm{a}} 0.77 \pm 0.10^{\mathrm{a}}$ & $0.30 \pm 0.01^{\mathrm{a}}$ \\
\hline & 15 & $48.43 \pm 1.42^{a} 50.59 \pm 0.72^{a}$ & $49.04 \pm 1.41^{\mathrm{a}}$ & $2.57 \pm 0.07^{\mathrm{a}} 0.37 \pm 0.04^{\mathrm{a}}$ & $0.15 \pm 0.00^{\mathrm{a}}$ & $5.30 \pm 0.30^{\mathrm{a}} 0.72 \pm 0.07^{\mathrm{a}}$ & $0.32 \pm 0.00^{\mathrm{a}}$ \\
\hline
\end{tabular}

Means in column with the same subscript are no different (P>0.05), P: Pressure (MPa), T: Time (min), C: Control, E: external, M: middle, I: Internal

Table 2 The changes in moisture and salt contents (mean \pm standard deviation) of white cheese samples HP treated for 15 min during ripening

\begin{tabular}{|c|c|c|c|c|c|c|c|c|}
\hline \multirow{2}{*}{$\mathrm{P}$} & \multicolumn{4}{|c|}{ Moisture (\%) } & \multicolumn{4}{|c|}{ Salt (\%) } \\
\hline & $1^{\text {rst }}$ day & $14^{\text {th }}$ day & $30^{\text {th }}$ day & $60^{\text {th }}$ day & $1^{\text {rst }}$ day & $14^{\text {th }}$ day & $30^{\text {th }}$ day & $60^{\text {th }}$ day \\
\hline $\mathrm{C}$ & $51.05 \pm 0.01^{\mathrm{a}^{*}}$ & $54.09 \pm 1.83^{\mathrm{a} \#}$ & $53.69 \pm 0.93^{\mathrm{a} \#}$ & $53.72 \pm 0.20^{\mathrm{a} \#}$ & $1.87 \pm 0.12^{\mathrm{a}^{*}}$ & $4.20 \pm 0.22^{\text {a\# }}$ & $4.06 \pm 0.03^{\mathrm{a} \#}$ & $3.94 \pm 0.06^{\mathrm{a} \#}$ \\
\hline 50 & $50.15 \pm 2.71^{\mathrm{a}^{*}}$ & $53.37 \pm 0.50^{\mathrm{a} \#}$ & $54.37 \pm 0.01^{\mathrm{a} \#}$ & $53.74 \pm 0.56^{\text {a\# }}$ & $1.83 \pm 0.11^{\mathrm{a}^{*}}$ & $4.20 \pm 0.04^{\mathrm{a} \#}$ & $4.20 \pm 0.25^{\mathrm{a} \#}$ & $4.23 \pm 0.03^{\mathrm{a} \#}$ \\
\hline 100 & $51.60 \pm 1.58^{\mathrm{a}^{*}}$ & $53.18 \pm 1.36^{\mathrm{a} \#}$ & $53.10 \pm 1.20^{\mathrm{a} \#}$ & $54.11 \pm 0.23^{\mathrm{a} \#}$ & $1.86 \pm 0.10^{\mathrm{a}^{*}}$ & $4.08 \pm 0.06^{\mathrm{a} \#}$ & $4.16 \pm 0.03^{\mathrm{a} \#}$ & $4.32 \pm 0.19^{\mathrm{a} \#}$ \\
\hline 200 & $51.70 \pm 1.01^{\mathrm{a}^{*}}$ & $53.41 \pm 1.49^{\text {a\# }}$ & $55.16 \pm 0.26^{\mathrm{a} \#}$ & $54.40 \pm 0.12^{\text {a\# }}$ & $1.71 \pm 0.02^{\mathrm{a}^{*}}$ & $4.13 \pm 0.19^{\text {a\# }}$ & $4.14 \pm 0.14^{\mathrm{a} \#}$ & $4.18 \pm 0.15^{\mathrm{a \#}}$ \\
\hline 400 & $51.64 \pm 1.18^{\mathrm{a}^{*}}$ & - & - & $55.60 \pm 1.08^{\text {a\# }}$ & $1.82 \pm 0.09^{\mathrm{a}^{*}}$ & - & - & $4.22 \pm 0.13^{\mathrm{a} \#}$ \\
\hline
\end{tabular}

Means in the same column with the same letter are no different ( $\mathrm{P}>0.05)$, Means in the same row with the same symbol are no different $(\mathrm{P}>0.05), \mathrm{P}$ : Pressure (MPa), C: Control
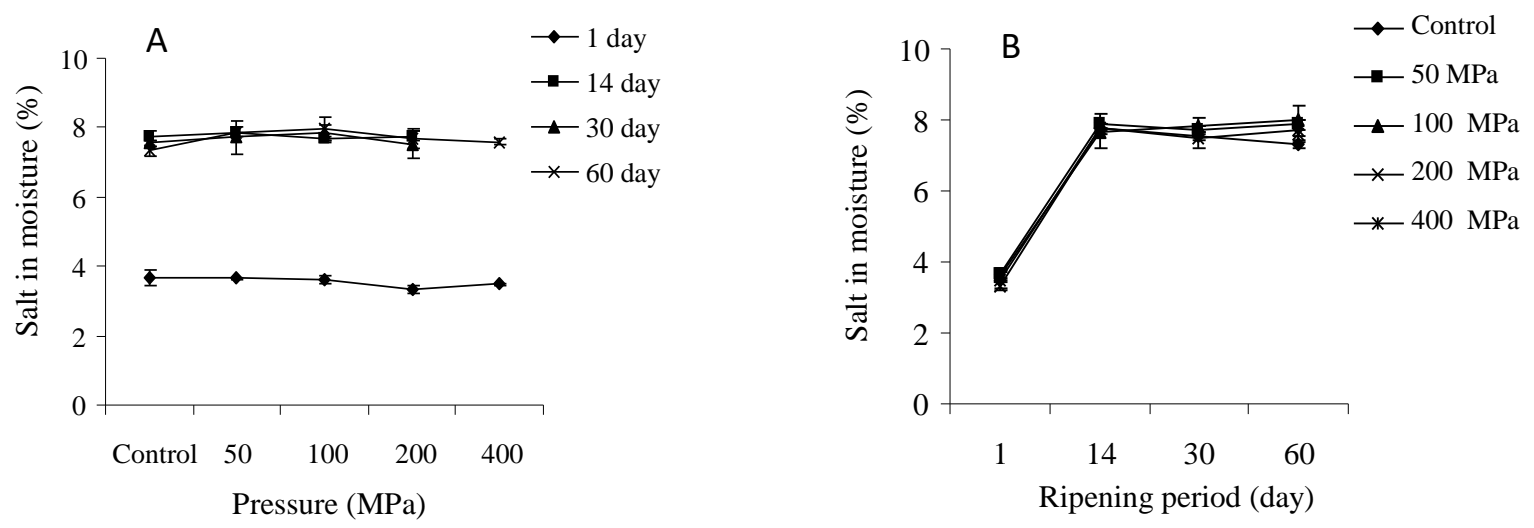

Figure 2 The salt-in-moisture values of samples HP treated for 15 min during ripening

Ripening time had a significant effect on salt and moisture contents of un-pressurized and pressurized cheese samples with an increase in these parameters until $14^{\text {th }}$ days of ripening $(\mathrm{P}<0.01)$. On the first day of ripening, the salt and moisture contents of cheese samples were around $1.71-1.88 \%$ and $50.05-51.70 \%$, respectively. It is very obvious from Table 2 , the salt contents for all treatments on day 14 increased more than twice, with the values of $4.08-4.20 \%$, while their moisture contents were $53.18-54.09 \%$. Then, the salt absorption from brine to cheese in tin was almost stopped after $14^{\text {th }}$ day of ripening. Moreover, the values of salt in moisture in cheese samples subjected to HP up to $200 \mathrm{MPa}$ were equilibrated within 14 days of ripening (Fig. 2a and 2b). The cheese samples subjected to $400 \mathrm{MPa}$ were analyzed on the $1^{\text {st }}$ and $60^{\text {th }}$ days of ripening. That is why; the data for $400 \mathrm{MPa}$ on the $14^{\text {th }}$ and $30^{\text {th }}$ days were missing. However, it is most possible to have equilibration in salt content of cheese sample pressurized at $400 \mathrm{MPa}$ on day
14 because of their softer texture. After 14 days of ripening, the changes in all variables were not significant (P>0.05, Fig. 2b) although there was a light increase in moisture of cheeses treated at 200 and $400 \mathrm{MPa}$. Uraz and Cencer (2000) investigated the effects of cheese size and amount of brine on the salt absorption of Turkish white cheese during brining and ripening, and determined that salt was absorbed very rapidly during the first 15 days of ripening, but then it was slow down.

\section{Conclusions}

High pressure processing at 50-400 MPa for 5-15 min on salted white cheese did not change the salt distribution and moisture content within cheese zones. Moreover, the salt uptake in whole cheese block was not affected by pressure application during ripening. Although processing at pressures of 200 and $400 \mathrm{MPa}$ for $15 \mathrm{~min}$ resulted in softer texture in cheese, a denser structure of them 
compensated the salt uptake during ripening. However, slightly increase in moisture at the pressures of 200-400 $\mathrm{MPa}$ on the $60^{\text {th }}$ day of ripening, which was not significant, might warn further increases in moisture during longer ripening periods than 60 days.

\section{Acknowledgments}

Authors would like to acknowledge JT Parker Dairy Chair for financial support. We also would like to thank The Ohio State University Food Industry Center USA personnel for their assistance.

\section{References}

Bradley RL, Arnold EA, Barbano DM, Semerad RG, Smith DE, Vines BK. 1992. Chemical and physical methods. In: (Ed. Marshall RT). Standard Methods For The Examination of Dairy Products. 16th Ed. Washington, D.C.: American Public Health Association. pp: 433-531. ISBN: 0-87553210-1.

Fox PF, Guinee TP, Cogan TM, McSweeney PLH. 2017. Salting of cheese curd. In: (Ed. Fox PF). Fundamentals of Cheese Science. 2nd Ed. New York, the USA: Springer. pp: 251-275. ISBN: 978-1-4899-7681-9.

Guamis B, Trujillo AJ, Ferragut V, Chiralt A, Andres A, Fito P. 1997. Ripening control of Manchego type cheese salted by brine vacuum impregnation. Int Dairy J, 7(2-3): 185-192. doi: 10.1016/S0958-6946(97)00002-2

Guinee TP. 2004. Salting and the role of salt in cheese. Int J Dairy Technol, 57(2-3): 99-109. doi: 10.1111/j.14710307.2004.00145.x

Guinee TP, Fox PF. 2004. Salt in cheese: physical and biological aspects. In: (Eds. Fox PF, McSweeney PLH, Cogan TM, Guinee, TP). Cheese: Chemistry, Physics and Microbiology. 3rd Ed. Volume 1, General Aspects. London: Elsevier. pp: 207-259. ISBN: 978-0-12-263652-3.
Hayaloglu AA, Guven M, Fox PF. 2002. Microbiological, biochemical and technological properties of Turkish white cheese 'Beyaz Peynir'. Int Dairy J, 12(8): 635-648. doi: 10.1016/S0958-6946(02)00055-9

ISO 707/IDF 50. 2008. Milk and milk products: Guidance on sampling, international standart, Organization for Standardization and International Dairy Federation, Switzerland.

Koca N, Balasubramaniam VM, Harper WJ. 2011. Highpressure effects on the microstructure, texture, and color of white-brined cheese. J Food Sci, 76(5): 399-404. doi: 10.1111/j.1750-3841.2011.02201.x

Kolakowski P, Reps A, Babuchowski A. 1998. Characteristics of pressurized ripened cheeses. Pol Food and Nutr Sci, 7(3): 473-482.

Luna JA, Chavez MS. 1992. Mathematical model for water diffusion during brining of hard and semi-hard cheese. J Food Sci, 57(1): 55-58. doi: 10.1111/j.13652621.1992.tb05423.x

Messens W, De Walle DV, Arovalo J, Dewettinck K, Huyghebaert A. 2000. Rheological properties of high pressure treated Gouda cheese. Int Dairy J, 10(5-6): 359367. doi: 10.1016/S0958-6946(00)00066-2

Messens W, Dewettinck K, Huyghebaert A. 1999. Transport of sodium chloride and water in Gouda cheese as affected by high-pressure brining. Int Dairy J, 9(8): 569-576. doi: 10.1016/S0958-6946(99)00126-0

Pavia M, Trujillo AJ, Guamis B, Ferragut V. 2000. Effectiveness of high-pressure brining of Manchego-type cheese. Food Sci Technol - LEB, 33(5): 401-403. doi: 10.1006/fstl.2000.0673

Uraz T, Cencer N. 2000. The effect of block size and amount of brine on the salt absorption in white pickled cheese. Turk $\mathbf{J}$ Agric For, 24(5): 621-628.

Wick C, Nienaber U, Anggraeni O, Shelhammer TH, Courtney PD. 2004. Texture, proteolysis and viable lactic acid bacteria in commercial Cheddar cheeses treated with high pressure. J Dairy Res, 71(1): 107-115, doi: $10.1017 /$ S0022029903006587 